\title{
Identifikasi Kesulitan Guru Matematika Dalam Pelaksanaan Pembelajaran Daring di Masa Pandemi Covid-19
}

\author{
Ridhatul Husna*, Yenita Roza, Maimunah \\ PPs Pendidikan Matematika, FKIP Universitas Riau \\ *Corresponding Author. Email: ridhatulhusna86@gmail.com
}

\begin{abstract}
This study aims to identify the difficulties of mathematics teachers in carrying out their roles as teachers in online learning from the aspect of teachers as learning resources, demonstrators, motivators, managers, and evaluators. This research method is descriptive qualitative. The subjects were $25 \mathrm{SMA} / \mathrm{MA}$ mathematics teachers in Kabupaten Kuantan Singingi Riau Province. The data collection technique used an instrument in the form of a questionnaire. Data were analyzed using descriptive statistics. Based on the research results of the five indicators of the teacher's role, teachers have difficulty, especially in carrying out their role as demonstrators $62 \%$, roles as motivators $50 \%$, and roles as evaluators $50 \%$.
\end{abstract}

\begin{abstract}
Abstrak: Penelitian ini bertujuan untuk mengidentifikasi kesulitan guru matematika dalam melaksanakan perannya sebagai guru pada pembelajaran daring dari aspek guru sebagai sumber belajar, demonstrator, motivator, pengelola, dan evaluator. Metode penelitian ini adalah deskriptif kualitatif. Subjeknya adalah 25 orang guru matematika SMA/MA di Kabupaten Kuantan Singingi Provinsi Riau. Teknik pengumpulan data menggunakan instrumen angket. Data dianalisis dengan statistik deskriptif. Hasil penelitian ini menunjukkan bahwa berdasarkan lima indikator peran guru, guru kesulitan terutama dalam melaksanakan peran sebagai demonstrator $62 \%$, peran sebagai motivator $50 \%$, dan peran sebagai evaluator $50 \%$.
\end{abstract}

\section{Article History}

Received: 04-01-2021

Revised: 25-02-2021

Accepted: 20-04-2021

Published: 07-06-2021

\author{
Key Words: \\ Difficulty, Online \\ Learning, Teacher \\ Role.
}

\section{Sejarah Artikel \\ Diterima: 04-01-2021 \\ Direvisi: 25-02-2021 \\ Disetujui: 20-04-2021 \\ Diterbitkan: 07-06-2021}

\section{Kata Kunci:}

Kesulitan, Pembelajaran Daring, Peran Guru.

How to Cite: Husna, R., Roza, Y., \& Maimunah, M. (2021). Identifikasi Kesulitan Guru Matematika Dalam Pelaksanaan Pembelajaran Daring di Masa Pandemi Covid-19. Jurnal Kependidikan: Jurnal Hasil Penelitian dan Kajian Kepustakaan di Bidang Pendidikan, Pengajaran dan Pembelajaran, 7(2), 428-436. doi:https://doi.org/10.33394/jk.v7i2.3333

https://doi.org/10.33394/jk.v7i2.3333

This is an open-access article under the CC-BY-SA License.

\section{Pendahuluan}

Pandemi Covid-19 sedang melanda berbagai negara pada saat ini, tak terkecuali Indonesia. Pemerintah Indonesia melakukan beberapa tindakan sebagai antisipasi penyebaran Covid-19, mulai dari kampanye di rumah saja, social and physical distancing, hingga pembatasan sosial berskala besar (PSBB). Masyarakat dianjurkan oleh pemerintah untuk tetap berada di rumah, bekerja di rumah, beribadah di rumah, dan belajar di rumah bagi para siswa (Rigianti, 2020).

Sehubungan dengan itu, Menteri Pendidikan dan Kebudayaan (Mendikbud) mengeluarkan surat edaran Nomor 4 Tahun 2020 tentang Pelaksanaan Kebijakan Pendidikan dalam Masa Darurat Penyebaran Coronavirus Disease (Covid-19) dimana surat ini mempertimbangkan beberapa pelaksanaan yang harus dilakukan satuan pendidikan dalam pencegahan Covid-19 salah satunya yaitu proses pembelajaran dilaksanakan dari rumah atau secara daring dengan ketentuan sebagai berikut: a) Belajar dari rumah melalui pembelajaran daring/jarak jauh dilaksanakan untuk memberikan pengalaman belajar yang bermakna bagi siswa, tanpa terbebani tuntutan menuntaskan seluruh capaian kurikulum untuk kenaikan kelas maupun kelulusan; b) Belajar dari rumah dapat difokuskan pada pendidikan kecakapan hidup 
antara lain mengenai pandemi Covid-19; c) Aktivitas dan tugas Belajar dari Rumah dapat bervariasi antar siswa, sesuai minat dan kondisi masing-masing, termasuk mempertimbangkan kesenjangan akses/fasilitas belajar di rumah; d) Bukti atau produk aktivitas Belajar dari Rumah diberi umpan balik yang bersifat kualitatif dan berguna dari guru, tanpa diharuskan memberi skor/nilai kuantitatif. Mendikbud juga mengeluarkan Surat Edaran Nomor : 36962/MPK.A/HK/2020 tanggal 17 Maret 2020 perihal : Pembelajaran secara daring dan bekerja dari rumah dalam rangka Pencegahan Penyebaran Corona Virus Disease (Covid-19). Dalam surat tersebut Kementerian menghimbau kepada pegawai, guru, dan dosen melakukan aktivitas bekerja, mengajar atau memberi kuliah dari rumah (Bekerja Dari Rumah / BDR) melalui video conference, digital documents, dan sarana daring lainnya.

Musibah pandemi ini sangat mempengaruhi sistem pendidikan sehingga proses pembelajaran harus dilakukan melalui pembelajaran daring. Pembelajaran daring merupakan salah satu metode pembelajaran yang dilaksanakan secara online atau pembelajaran melalui jaringan internet (Mustofa, 2019). Pembelajaran daring juga merupakan bentuk penyampaian pembelajaran konvensional yang dilaksanakan dalam format digital dengan menggunakan jaringan internet (Imania, 2019).

Pembelajaran secara daring yang dilaksanakan selama masa pandemi Covid-19 maupun pembelajaran daring konsisten banyak ditemukan kendala baik oleh siswa maupun guru. Pada penelitian Utami dan Cahyono (2020) disampaikan bahwa kendala akses internet atau jaringan mengganggu aktifitas siswa, siswa kesulitan dalam mengerjakan pelajaran matematika karena tugas yang diberikan oleh guru jumlahnya banyak, dan siswa kurang berminat belajar daring karena mereka kurang mampu belajar mandiri, dan siswa sulit untuk memahami pembelajaran dalam jaringan. Selanjutnya Erni (2020) juga mengemukakan bahwa saat pemerintah menganjurkan menggunakan aplikasi pembelajaran online, guru dengan segera membuat wa-group sebagai media komunikasi awal. Namun muncul permasalahan bahwa tidak semua siswa mempunyai nomor WhatsApp (WA), terkadang yang mempunyai nomor WA hanya ayahnya atau ibunya saja. Jaringan internet yang kurang lancar juga menjadi kendala dalam melakasanakan pembelajaran online, sehingga siswa tidak aktif dalam pembelajaran tersebut. Karena kondisi seperti ini, gurupun akhirnya hanya mengirimkan file pembelajaran dan tugas kepada siswa.

Pada proses pembelajaran secara daring di tengah pandemi Covid-19, peranan teknologi informasi sangat membantu sehingga proses pembelajaran dapat berjalan dengan baik (Pakpahan \& Fitriani, 2020). Namun, guru sebagai tenaga pendidik juga mengalami kesulitan dalam melaksanakan pembelajaran secara daring. Rigianti (2020) mengemukakan bahwa kendala yang dialami guru sekolah dasar di Banjarnegara ketika melaksanakan pembelajaran daring diantaranya aplikasi pembelajaran dimana $100 \%$ guru menggunakan aplikasi WhatsApp, jaringan internet dan gawai, pengelolaan pembelajaran yang sulit, kesulitan dalam penilaian, dan pengawasan.

Pelaksanaan pembelajaran daring mengakibatkan peran guru dalam proses pembelajaran tidak terlaksana secara maksimal. Meskipun pembelajaran dilakukan secara daring tetapi pada dasarnya pada proses pembelajaran peran guru harus tetap dilaksanakan. Handayani (2020) mengemukakan selain kendala jaringan, interaksi sepihak menjadi kelemahan dalam pembelajaran daring dengan kualitas interaksi di lingkungan pendidikan yang buruk. Guru membuat kemajuan sendiri tanpa interaksi dengan siswa. Salah satu tantangan dalam penerapan pendidikan jarak jauh adalah guru/dosen yang belum terbiasa dengan pembelajaran online (Kahfi, 2020).

Matematika merupakan salah satu mata pelajaran yang penting dalam pendidikan, dilihat dari pelaksanaannya mulai dari tingkat sekolah dasar hingga tingkat sekolah 
menengah. Meskipun menjadi mata pelajaran yang sangat penting, matematika masih dianggap menjadi mata pelajaran yang sulit bagi siswa karena objek matematika yang abstrak menggunakan banyak rumus (Utami, 2020). Ketika belajar di sekolah guru menyampaikan materi kepada siswa secara langsung di kelas, menjelaskan materi secara rinci, serta dapat memantau langsung pemahaman siswa terhadap materi yang disampaikan. Apabila ada siswa yang kesulitan atau kurang paham guru dapat langsung memberi penjelasan kepada siswa. Akan tetapi akibat pendemi Covid-19 mengharuskan guru mengajar melalui daring, sehingga penyampaian materi pun kurang maksimal karena berbagai kendala yang ditemui dalam pelaksanaan pembelajaran. Guru tidak memberikan penjelasan yang langkap dan rinci sehingga siswa mengalami kesulitan dalam memahami materi.

Guru sebagai tenaga pendidik harus memiliki kemampuan teknologi dengan model pembelajaran jarak jauh atau daring agar materi pelajaran tersampaikan dengan baik. Pada proses pembelajaran daring, guru matematika belum sepenuhnya mempertahankan substansi materi atau memperhatikan kualitas konten materi yang disampaikan (Giantara \& Astuti, 2020). Adapun penelitian ini bertujuan untuk mengidentifikasi kendala yang dialami guru matematika pada pelaksanaan pembelajaran daring dalam mengimplementasikan perannya sebagai guru. Peran pokok guru dalam proses pembelajaran yaitu guru sebagai demonstrator, guru sebagai pengelola kelas, guru sebagai mediator dan fasilitator, dan guru sebagai evaluator (Buchari, 2018).

\section{Metode Penelitian}

Penelitian ini menggunakan metode penelitian deskriptif kualitatif untuk memberikan gambaran kesulitan yang dialami guru matematika SMA/MA berstatus PNS dan juga honor di Kabupaten Kuantan Singingi Provinsi Riau dalam melaksanakan peran guru pada proses pembelajaran secara daring. Subjek penelitian adalah 25 orang guru matematika dari 13 SMA/MA negeri di Kabupaten Kuantan Singingi yang mengajar di kelas X, XI, dan XII. Teknik pengumpulan data dilakukan dengan pengisian angket dengan menggunakan google form agar mudah diakses oleh guru.

Prosedur pelaksanaan penelitian ini adalah sebagai berikut : 1) Tahap perencanaan, menyusun instrument penelitian yaitu angket kesulitan peran guru pada proses pembelajaran daring. 2) Tahap Pelaksanaan, pemberian angket kepada 25 orang guru matematika SMA di Kabupaten Kuantan Singingi. 3) Tahap analisis data, menganalisis hasil angket yang telah diberikan kepada subjek penelitian. 4) Tahap pelaporan, membuat dan menyusun laporan berdasarkan hasil analisis data yang telah dilakukan.

Instrument penelitian ini adalah angket kesulitan guru matematika dalam melaksanakan perannya sebagai guru pada proses pembelajaran daring. Adapun peran guru tersebut adalah : 1) Guru sebagai sumber belajar. Guru sebagai sumber belajar harus menguasai materi sehingga dapat menjelaskan materi kepada siswa dengan baik, mampu membuat pemetaan tentang materi pelajaran, serta memiliki dan menggunakan berbagai macam sumber belajar. 2) Guru sebagai demonstrator. Sebagai demonstrator, guru harus mampu menjadikan siswa agar lebih memahami materi pelajaran serta mampu menerapkan berbagai strategi atau metode pembelajaran. 3) Guru sebagai motivator. Sebagai motivator, guru harus mampu memotivasi siswa untuk mengikuti pembelajaran dengan baik serta mengajak siswa aktif dalam proses pembelajaran. 4) Guru sebagai pengelola. Guru sebagai pengelola dalam kegiatan pembelajaran harus mampu menyampaikan semua materi pelajaran tepat waktu dan mampu mengoperasikan berbagai media atau aplikasi agar kegiatan pembelajaran berjalan dengan lancar. 5) Guru sebagai evaluator. Sebagai evaluator guru 
harus mampu melakukan penilaian secara objektif sesuai dengan kemampuan siswa dan mengetahui perkembangan prestasi belajar siswa.

Teknik analisis pada penelitian ini dilakukan melalui data dan informasi hasil studi angket dengan menggunakan statistik deskriptif untuk mengetahui persentase kesulitan guru matematika dalam melaksanakan perannya sebagai guru dengan pembelajaran daring pada materi awal semester ganjil tahun pelajaran 2020/2021.

\section{Hasil Penelitian dan Pembahasan}

Proses belajar mengajar secara daring sudah berlangsung dari bulan Maret 2020 karena adanya wabah pandemi Covid-19 . Pembelajaran daring menjadi hal yang baru bagi siswa maupun kalangan guru. Memasuki tahun pelajaran 2020/2021 pembelajaran masih dilaksanakan secara daring. Namun, guru masih menemui berbagai kesulitan atau kendala dalam pelaksanaan pembelajaran daring terutama dalam melaksanakan perannya sebagai guru.

\section{Guru Sebagai Sumber Belajar}

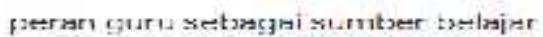

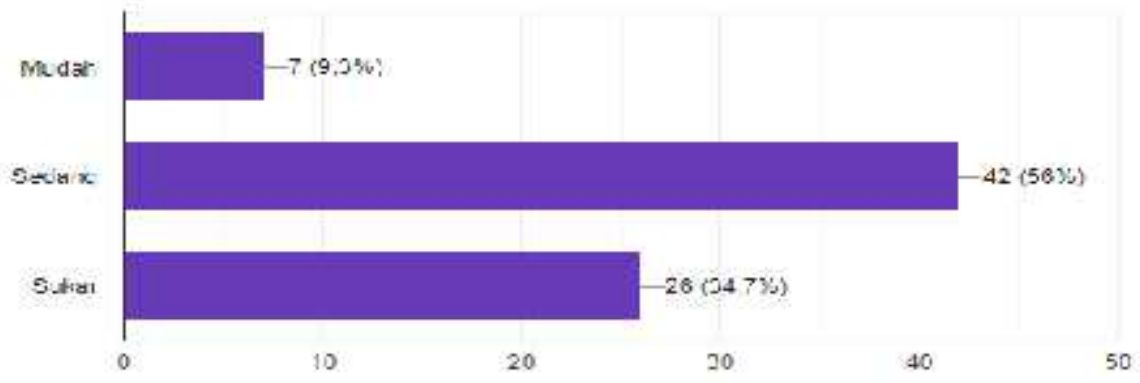

Gambar 1. Melaksanakan Peran Guru sebagai Sumber Belajar

Guru sebagai sumber belajar bagi siswa merupakan peran yang sangat penting. Peran guru sebagai sumber belajar berkaitan erat dengan penguasaan materi pelajaran. Guru harus memiliki pemahaman yang lebih baik tentang materi yang akan disajikan, sehingga mampu menjelaskan materi pembelajaran meskipun secara daring. Pada pelaksanaan pembelajaran daring guru mengalami kesulitan dalam menyampaikan materi pelajaran, sebagai contoh jika ada siswa yang tidak memahami materi guru tidak dapat secara langsung menjelaskannya. Guru dikatakan baik jika menguasai materi pelajaran dengan baik dan mampu menyampaikan kepada siswa, sehingga guru benar-benar berperan sebagai sumber belajar bagi siswa. Pemetaan tentang materi pelajaran perlu dilakukan oleh guru, misalnya dengan menentukan mana materi inti yang wajib dipelajari oleh siswa, kemudian mana materi yang harus diingat kembali, dan mana materi tambahan. Hal ini akan memudahkan guru dalam melaksanakan tugasnya sebagai sumber belajar. Berdasarkan Gambar 1 di atas, sebagian guru matematika masih mengalami kesulitan dalam melakukan pemetaan tentang materi pelajaran yang akan diajarkan kepada siswa secara daring. Sehingga peran guru sebagai sumber belajar akan sulit dilaksanakan dengan baik.

Guru sebagai sumber belajar harus dapat menunjukkan sumber belajar yang dapat dipelajari oleh siswa mengenai materi pelajaran yang akan dipelajari melalui pembelajaran daring. Pada pembelajaran daring, banyak sumber-sumber belajar yang dapat digunakan dan diberikan guru kepada siswa seperti modul, powerpoint tentang materi pelajaran, lembar kerja siswa, buku, dan sebagainya. Akan tetapi belum tentu semua siswa paham dengan materi yang diberikan tersebut dan siswa hanya memahami materi menurut tafsiran atau 
sudut pandang mereka sendiri (Asmuni, 2020). Sumber belajar yang digunakan dalam pembelajaran matematika harus diperhatikan dengan baik dan dibuat semenarik mungkin agar siswa senang belajar matematika dan tujuan pembelajaran tercapai.

\section{Guru Sebagai Demostrator}

peran guru sebagal demonstrator

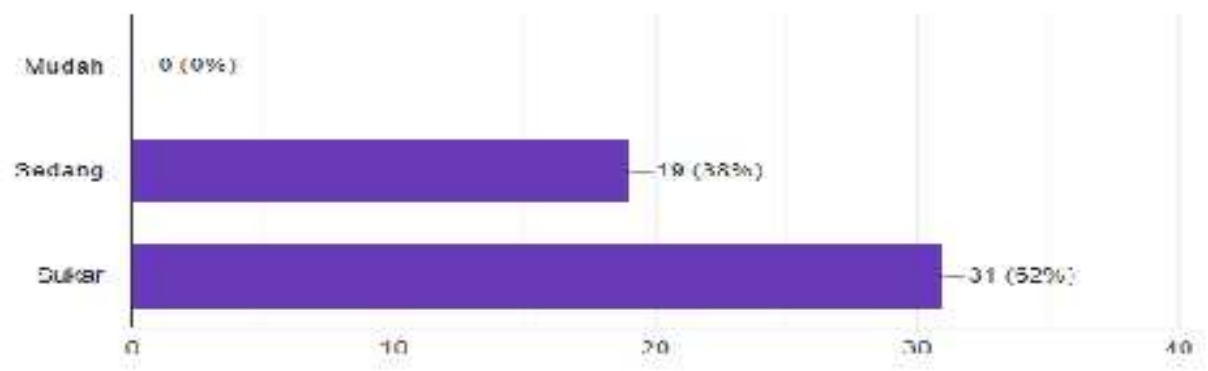

Gambar 2. Melaksanakan Peran Guru sebagai Demonstrator

Guru sebagai demonstrator merupakan suatu peran untuk mempertunjukkan kepada siswa segala sesuatu yang dapat membuat siswa lebih mengerti dan memahami setiap pesan yang disampaikan oleh guru (Saifuddin, 2018). Matematika sebagai mata pelajaran yang identik dengan angka dan rumus mengharuskan guru mampu menggunakan berbagai strategi agar siswa memahami pelajaran yang diberikan.

Dalam matematika objek dasar yang dipelajari adalah abstrak yang meliputi simbol dan konsep. Sehingga sebagian siswa mengalami kesulitan untuk memahami materi-materi dalam matematika. Peran guru sebagai demonstrator hendaknya mampu membuat siswa memahami materi pelajaran. Gambar 2 menunjukkan bahwa 62\% guru matematika SMA mengalami kesulitan dalam melaksanakan perannya sebagai demonstrator, yaitu agar siswa dapat mengerti dan memahami materi yang diberikan melalui pembelajaran daring. Hal ini terjadi terjadi karena ketika siswa belum memahami materi yang diberikan, guru tidak bisa secara langsung menjelaskannya kepada siswa. Sejalan dengan penelitian Taradisa (2020), bahwa siswa kurang memahami materi pelajaran yang diajarkankan oleh guru karena proses pembelajaran tidak bertatap muka langsung.

Guru sebagai demonstrator hendaknya mampu menyajikan materi pelajaran agar dipahami oleh siswa. Oleh sebab itu, guru hendaknya menerapkan berbagai strategi atau metode pembelajaran yang tepat agar siswa memahami materi pelajaran dan tujuan pembelajaran juga tercapai meskipun melalui pembelajaran daring. Guru matematika mengalami kesulitan dalam melaksanakan perannya sebagai demonstrator. Hal ini karena adanya interaksi sepihak dan materi tidak tersampaikan secara akurat. Agar pembelajaran daring berjalan dengan efektif, guru harus memiliki strategi-strategi yang baik, efektif, dan menyenangkan agar siswa lebih mudah menghadapi pembelajaran (Yuangga, 2020).

\section{Guru Sebagai Motivator}

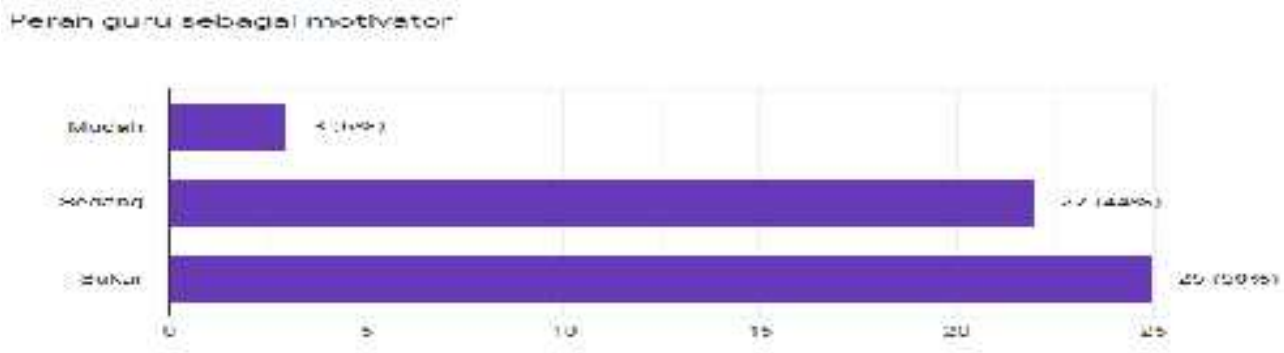

Gambar 3. Melaksanakan Peran Guru Sebagai Motivator

Jurnal Kependidikan Vol. 7. No. 2 : Juni 2021

Copyright $\odot$ 2021, Husna, R., Roza, Y., \& Maimunah, M. 
Guru sebagai motivator berperan penting dalam interaksi pembelajaran. Sebagai mata pelajaran yang identik dengan angka dan rumus membuat banyak siswa merasa takut untuk belajar matematika. Sebagai motivator, guru harus selalu memotivasi siswa agar tetap semangat dalam belajar. Selama pembelajaran daring, guru harus memberi motivasi kepada siswa agar tetap mengikuti pembelajaran dengan jarak jauh. Gambar 3 menunjukkan bahwa $50 \%$ guru matematika kesulitan dalam memotivasi siswa mengikuti pembelajaran daring. Ini menunjukkan bahwa siswa memiliki kemauan yang kurang dalam mengikuti pembelajaran daring. Menurut Hamzah dalam Fitriyani (2020), indikator motivasi belajar antara lain adalah kosentrasi, mandiri, rasa ingin tahu, semangat, rasa percaya diri, kesiapan, antusias, dan pantang menyerah.

Guru sebagai motivator merupakan sebagai pendorong bagi siswa dalam meningkatkan semangat mengikuti kegiatan pembelajaran. Keaktifan siswa dalam proses pembelajaran merupakan salah satu indikator yang menunjukkan bahwa siswa tersebut mempunyai motivasi belajar. Interaksi antara guru dengan siswa berkurang ketika pembelajaran dilakukan secara daring, yang mengakibatkan siswa juga kurang termotivasi untuk belajar. Guru sebagai motivator harus mengetahui motif-motif yang menyebabkan daya belajar siswa rendah, namun karena pembelajaran dilakukan secara daring mengakibatkan guru sulit mengetahui penyebab kurangnya motivasi belajar siswa. Seorang guru tidak hanya berperan dalam mentrasfer ilmu mata pelajarannya saja kepada siswa, tetapi guru juga sebagai motivator bagi siswa agar memiliki orientasi dalam balajar.

\section{Guru Sebagai Pengelola}

Poran guru scbagai pongelola

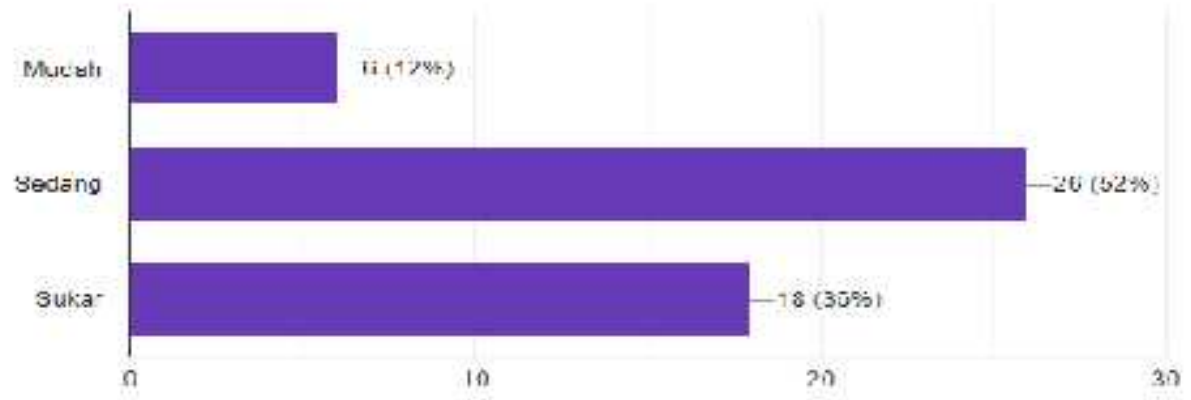

Gambar 4. Melaksanakan Peran Guru Sebagai Pengelola

Guru sebagai pengelola pembelajaran bertugas untuk mengelola pembelajaran dengan baik mulai dari perencanaan, pelaksanaan, hingga evaluasi. Pengelolaan pembelajaran yang baik akan membawa proses pembelajaran yang terlaksana dengan lancar dan memudahkan dalam pencapaian tujuan pembelajaran. Berdasarkan Gambar 4, sebagian guru matematika kesulitan melaksanakan peran sebagai pengelola pada pelaksanaan pembelajaran daring. Pengelolaan waktu pembelajaran perlu dipertimbangkan oleh guru, namun guru matematika kesulitan menyampaikan semua materi pelajaran dengan tepat waktu. Hal ini disebabkan karena pada pembelajaran daring jumlah jam pelajaran tidak sama dengan jumlah jam pelajaran tatap muka langsung dan juga materi yang akan disampaikan kepada siswa cukup banyak.

Pembelajaran jarak jauh merupakan pembelajaran yang siswanya terpisah dari guru, dan pembelajarannya menggunakan berbagai sumber belajar melalui teknologi komunikasi, informasi, dan media lainnya. Guru sebagai pengelola harus mampu mengoperasikan berbagai media atau aplikasi yang digunakan pada pembelajaran daring agar kegiatan 
pembelajaran terlaksana dengan baik. Namun tidak semua guru mampu mengoperasikan komputer atau gadget untuk mendukung kegiatan pembelajaran daring (Asmuni, 2020). Oleh sebab itu, guru dapat menggunakan aplikasi WhatsApp yang pengoperasiannya lebih sederhana dan terus meningkatkan kompetensi IT-nya.

\section{Guru Sebagai Evaluator}

peran guru acbagai covaltater

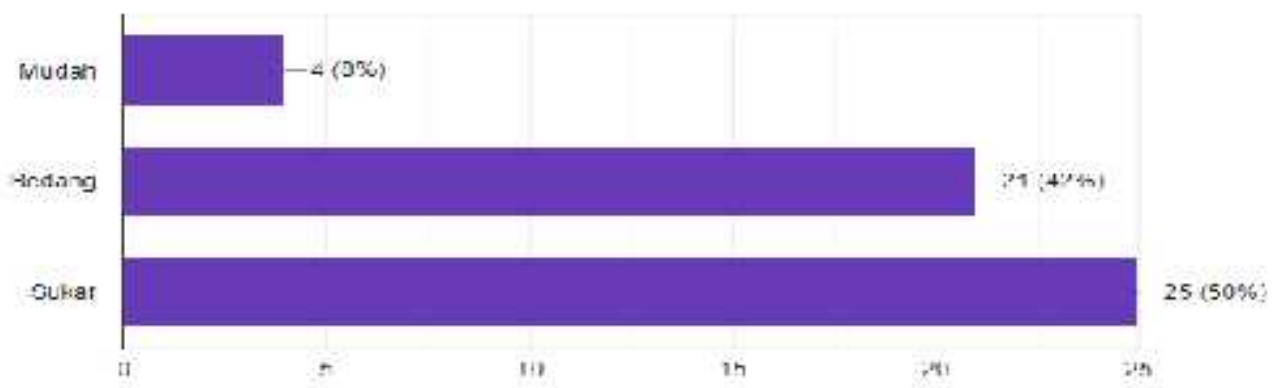

Gambar 5. Melaksanakan Peran Guru Sebagai Evaluator

Setelah melaksanakan berbagai kegiatan belajar dan melaksanakan berbagai peran sebagai guru dengan baik, selanjutnya guru harus melakukan evaluasi. Karena setiap periode pendidikan membutuhkan penilaian terhadap hasil yang telah dicapai. Dengan melakukan evaluasi seorang guru akan mengetahui tingkat kemampuan siswa dalam menerima materi pembelajaran. Pada pelaksanaan pembelajaran daring guru matematika mengalami kesulitan dalam melakukan penilaian kemampuan siswa karena guru tidak mengetahui apakah yang dikerjakan siswa benar-benar hasil kerjanya sendiri. Gambar 5 menunjukkan bahwa 50\% guru matematika kesulitan melaksanakan peran sebagai evaluator.

Menurut Nana Sudjana dalam Siagian (2012) menyatakan bahwa pencapaian prestasi belajar siswa berdasarkan pada pencapaian aspek kognitif, afektif, dan psikomotorik. Prestasi belajar yang dicapai merupakan hasil interaksi antar lingkungan. Namun dalam pembelajaran daring interaksi ini sulit dilakukan, sehingga guru kesulitan mengetahui prestasi belajar siswa. Sebagai evaluator, guru berperan untuk mengumpulkan informasi tentang keberhasilan pembelajaran yang telah dilakukan yang berfungsi untuk menentukan keberhasilan siswa dalam menyerap materi dan menentukan keberhasilan guru dalam melaksanakan proses pembelajaran. Guru kesulitan dalam menilai kemampuan siswa dan mengetahui perkembangan prestasi belajar siswa. Hal ini sejalan dengan penelitian Taradisa (2020), bahwa guru sulit dalam memantau perkembangan belajar siswa.

Evaluasi yang dilakukan dengan tujuan untuk menilai keberhasilan siswa pada proses pembelajaran secara daring sulit dilakukan, karena guru tidak dapat memantau secara lansung kerja siswa. Guru sulit mengetahui apakah tugas-tugas yang dikerjakan siswa merupakan hasil kerjanya sendiri atau diperoleh dari temannya. Karena melalui evaluasi guru dapat mengetahui apakah siswa sudah memiliki kompetensi yang ditetapkan sehingga siswa tersebut layak diberikan materi pembelajaran yang baru.

\section{Kesimpulan}

Kesimpulan dari penelitian ini adalah guru matematika mengalami kesulitan terutama dalam melaksanakan perannya sebagai demonstrator, motivator, dan evaluator. Guru dalam melaksanakan perannya sebagai demonstrator mengalami kesulitan agar siswa memahami setiap pesan yang disampaikan dan kesulitan dalam menentukan strategi yang digunakan supaya tujuan pembelajaran tercapai. Guru matematika kesulitan dalam melaksanakan 
perannya sebagai motivator karena sulit mengajak siswa agar aktif dalam kegiatan pembelajaran secara daring. Kemudian guru juga kesulitan dalam melaksanakan perannya sebagai evaluator karena guru tidak memantau secara langsung kegiatan belajar siswa, sehingga sulit mengetahui kemampuan dan perkembangan prestasi belajar siswa.

\section{Saran}

Hasil penelitian ini hendaknya menjadi bahan evaluasi bagi guru, sehingga kedepannya guru mampu mengatasi kesulitan dalam melaksanakan peran sebagai guru yang dialami selama pembelajaran daring dengan formula mengajar yang sesuai dengan kemampuan siswa. Dan untuk peneliti berikutnya diharapkan dapat menemukan formula atau cara mengajar daring agar kesulitan dalam melaksanakan peran sebagai guru pada pembelajaran daring dapat teratasi.

\section{Daftar Pustaka}

Asmuni, A. (2020). Problematika Pembelajaran Daring di Masa Pandemi Covid-19 dan Solusi Pemecahannya. Jurnal Paedagogy, 7(4), 281-288. doi:https://doi.org/10.33394/jp.v7i4.2941

Buchari, A. (2018). Peran Guru Dalam Pengelolaan Pembelajaran. Jurnal Ilmiah Iqra', 12(2), 106-124.

Erni, S., Vebrianto, R., Raudhatul, C. M., Amir, Z., Martius, \& Thahir, M. (2020). Refleksi Proses Pembelajaran Guru MTs dimasa Pendemi Covid 19 di Pekanbaru : Dampak dan Solusi. Bedelau: Journal of Education and Learning, 1(1), 1-10.

Fitriyani, Y., Fauzi, I., \& Sari, M. (2020). Motivasi Belajar Mahasiswa Pada Pembelajaran Daring Selama Pandemik Covid-19. Jurnal Kependidikan: Jurnal Hasil Penelitian dan Kajian Kepustakaan di Bidang Pendidikan, Pengajaran dan Pembelajaran, 6(2), 165-175. doi:https://doi.org/10.33394/jk.v6i2.2654

Giantara, F., \& Astuti. (2020). Kemampuan Guru Matematika Mempertahankan Substansi Materi Melalui Proses Pembelajaran Online. Jurnal Cendekia: Jurnal Pendidikan Matematika, 4(2), 787-796.

Handayani, L. (2020). Keuntungan, Kendala dan Solusi Pembelajaran Online Selama Pandemi Covid-19 : Studi Ekploratif di SMPN 3 Bae Kudus. Journal Industrial Engineering \& Management Research ( JIEMAR), 1(2), 15-23.

Imania, K. A., \& Bariah, S. K. (2019). Rancangan Pengembangan Instrumen Penilaian Pembelajaran Berbasis Daring. Jurnal Pendidikan Teknologi Informasi dan Komunikasi (PETIK), 5(1), 31-47.

Kahfi, A. (2020). Tantangan dan Harapan Pembelajaran Jarak Jauh di Masa Pandemi Covid 19. Dirasah : Jurnal Pemikiran dan Pendidikan Dasar Islam, 3(2), 137-154.

Menteri Pendidikan. (2020). Surat Edaran Nomor 4 Tahun 2020 Tentang Pelaksanaan Kebijakan Pendidikan Dalam Masa Darurat Penyebaran Coronavirus Disease (Covid19).

Menteri Pendidikan. (2020). Surat Edaran Mendikbud : Pembelajaran Secara Daring dan Bekerja dari Rumah dalam Rangka Pencegahan Penyebaran Coronavirus Disease (Covid-19).

Mustofa, M. I., Chodzirin, M., \& Sayekti, L. (2019). Formulasi Model Perkuliahan Daring Sebagai Upaya Menekan Disparitas Kualitas Perguruan Tinggi. Walisongo Journal of Information Technology, 1(2), 151-160. 
Pakpahan, R., \& Fitriani, Y. (2020). Analisa Pemanfaatan Teknologi Informasi Dalam Pembelajaran. JISAMAR (Journal of Information System, Applied, Management, Accounting and Researh), 4(2), 30-36.

Rigianti, H. A. (2020). Kendala Pembelajaran Daring Guru Sekolah Dasar Di Kabupaten Banjarnegara. Jurnal Elementary School, 7(2), 297-302.

Saifuddin. (2018). Pengelolaan Pembelajaran Teoretis dan Praktis. Yogyakarta : Deepublish.

Siagian, R. E. (2012). Pengaruh Minat dan Kebiasaan Belajar Siswa Terrhadap Prestasi Belajar Matematika. Jurnal Formatif : Jurnal Ilmiah Pendidikan MIPA, 2(2), 121131.

Taradisa, N., Jarmita, N., \& Emalfida. (2020). Kendala Yang Dihadapi Guru Mengajar Daring Pada Masa Pandemi Covid-19 Di MIN 5 Banda Aceh. UIN Ar-Raniry, 1-11.

Utami, Y. P., \& Cahyono, D. A. (2020). Study At Home: Analisis Kesulitan Belajar Matematika Pada Proses Pembelajaran Daring. Jurnal Ilmiah Matematika Realistik (JI-MR), l(1), 20-26.

Yuangga, K. D., \& Sunarsi, D. (2020). Pengembangan Media dan Strategi Pembelajaran Untuk Mengatasi Permasalahan Pembelajaran Jarak Jauh di Pandemi Covid- 19. Jurnal Guru Kita, 4(3), 51-58. 